Islamiconomic: Jurnal Ekonomi Islam

Volume 12 No. 1 January - June 2021

P-ISSN: 2085-3696; E-ISSN: 2541-4127

Page: 93 - 107

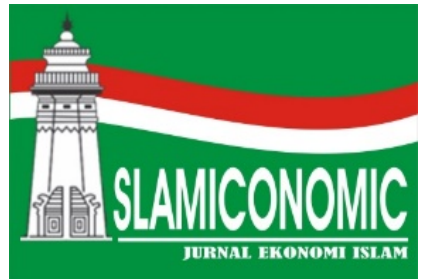

ISLAMICONOMIC: Jurnal Ekonomi Islam

Department of Islamic Economics

Faculty of Islamic Economics and Business

Universitas Islam Negeri Sultan Maulana Hasanuddin Banten

Jalan Jenderal Sudirman No. 30 Serang 42118

BANTEN - INDONESIA

Phone: +62254 200323 || Fax: +62254 200022 || Website: www. journal.islamiconomic.or.id

\title{
THE FRAME OF SHARIA ECONOMIC ON PAYLATER PAYMENT SYSTEM
}

\section{Rif'atul Muzayanah Al-Mahbubah, ${ }^{1}$ Ana Nurwakhidah,, ${ }^{2}$}

12 Universitas Islam Raden Rahmat, Malang, Indonesia

${ }^{*}$ Corresponding author: anan.jameelah@gmail.com

Information
Article History:
Received : 25.05 .2021
Revised : 13.06 .2021
Accepted : 20.06 .2021

Keywords: E-Commerce, PayLater, Bai 'As-Salam

\begin{abstract}
:
This study aims to investigate the payment system mechanism in Paylater in Shopee e-commerce, as well as to find out the contract used in the payment system and to review the system in the frame of Islamic law. This research was prompted upon a loan system namely Paylater provided by Shopee e-commerce, one of the biggest markerplaces in Indonesia, which offers loans with installment system. The method used in this research was a field research method. In this study, the researchers gathered data by themselves. The data was obtained from the application regarding public knowledge of Paylater Shoppe payments. The results showed that the payment system mechanism is relatively easy to follow since the application provides simple and practical instructions. Meanwhile, the contract used in Paylater payments is bai 'as-salam, where there are still similarities and differences that still need to be studied. In conclusion, in a review of Islamic law the Paylater system is categorized as usury and gharar.
\end{abstract}




\section{A. INTRODUCTION}

In social life, humans are always in touch with each other to make ends meet whether we realize it or not. (Azhar Basyir, 2000). In meeting their needs, one of so many ways is through exchanging activity such as sales and purchases transactions. Sales and purchases is an agreement to exchange objects or valuable goods between two parties voluntarily, one receiving the objects and the other party receiving the exchange tool (i.e. money) in return in accordance with the agreements or conditions that have been justified and agreed upon. (Hendi, 2002). Purchasing and selling certainly cannot be done haphazardly; there are certain rules that bind it, especially if the transaction is associated with religion.

Purchasing and selling transactions are also identified as muamalah, the meaning of muamalah in a broad sense is the law of Allah to govern humans in relation to worldly affairs. The narrow definition of muamalah is the rules of Allah that regulate the relationship between humans and other humans in relation to acquiring and developing property. Purchasing and selling transaction prevailing thereupon has undergone many changes nowadays since the development of technology. One of the real forms of technological development is the internet in which people start to moving on from the real market to virtual market.

Technology is a tool that we use to assist us in our activities to reduce uncertainty caused by the causal relationship in achieving goals. (Noegroho, 2010). Technology has offered humans with the ease of finding things that were not known before. Through the advancement of communication technology, a medium called the internet was created and began to spread widely as a medium of communication and information media. The internet has developed rapidly and by far has influenced all aspects of human life significantly. The internet helps humans to interact, communicate, and even do trade with other people from all over the world easily, quickly and cheaply. The internet is a large interconnected computer networks that connect people and computers around the world, via telephone, satellite and other communication systems. (Nugroho, 2019).

With the benefits of the internet, the heaps of business that use internet as a medium which so called as online business started to emerge. One of the internet 
Rif'atul Muzayanah et al: The Frame of Sharia Economic...

utility is as a platform of online business and as a medium for trading and purchasing. Previously, the only known payment instruments were just Kartal and Giral money. Rapid technological advances has supported the advancement of an increasingly diverse system or payment alternatives. Many services are offered by banks, one of which is debit, credit, and e money payment tools. (Ramdhan, 2017).

With the rapid development of internet technology, not only basic needs such as food and clothing, but also supporting needs such as means of transportation (motorbikes, cars), communication (smartphones), and other entertainment needs can also be accessed with internet media.

E-commerce or electronic commerce is a platform of the distribution, purchase, and marketing of service and goods through electronic systems or other computer networks. (Yulaika, 2018). E-commerce involves electronic fund transfers, electronic data exchange, automatic inventory management systems and automatic data collection systems. E-commerce is a smaller part of e-business, since the scope of ebusiness is broader, not only for commerce but also for collaborating with business partners, customer services, job vacancies, etc. In addition to network technology, ecommerce also requires database or database technology, electronic mail (e-mail), and other forms of non-computer technology such as goods delivery systems, and payment instruments for e-commerce.

In conventional way, transaction of purchasing and selling uses cash as a payment method. The cash payment method means paying directly with physical cash right away. This is commonly used in the market or grocery store with fewer nominal transactions. With the development of technology, now people can make cashless payment, a non-cash payment method. The cashless payment method, literally means no cash, and is used through electronic media such as debit cards or virtual wallets. (Assauri, 2018).

When people have desires yet the desires are not commensurate with their financial condition, it is better to hold up by saving money. However, since it will take a while for the money to be collected, some people will just use another alternative such as using the PayLater payment system. The PayLater payment system is the latest service feature provided by Shopee to offer loans to it's users of up to IDR. 750,000 . 
Islamiconomic: Jurnal Ekonomi Islam Vol.12 No.1 January - June 2021

Shopee provides instant loans up to Rp. 750,000., which make it easier for customer to pay in 1 month without interest or with 2 and 3 month installment facilities without credit card. So do customers can apply $1 \mathrm{x}$ additional limit for Shopee PayLater. (Jadmikio, 2020).

\section{B. LITERATUR REVIEW}

\section{Sales and purchases}

Terminologically, sales and purchases activity is an agreement to exchange things or valuable goods voluntarily between two parties, one party receiving the goods and the other party receiving the return in accordance with the agreement or provisions that have been allowed by syara' (Hendi, 2002). Sales and purchases also aim to make a profit.

The issue of sales and purchases in Islamic Fiqh is widely discussed by scholars of Fiqh, thus, this topic is found in various literatures (Aziz, 2004). Many scholars have also defined the term of sales and purchases (Az Zuhaili, 2011) such as Hanafi who defined sales and purchases as the exchange of goods or property for goods or property belong to another person which is done in a certain way or exchanging valuable goods in a rightful law through ijab qabul. According to Imam Nawawi, sales and purchases is the exchange of goods for goods for the purpose of member ownership. Meanwhile, according to Ibn Qudamah, sales and purchases is the

exchange of goods for goods with the aim of giving ownership and receiving property rights.

According to the scholars of the Maliki, Syafi'i, and Hanbali, sales and purchases is the exchange of property for property in the form of property and ownership transfer. In this case, they emphasize the word "property and ownership," because there is also the exchange of property that is not an ownership, such as rent (Ijarah) (Dahlan Aziz, 2014).

Online sales and purchases activities are currently increasingly prevalent, since the commerce sites and platform used are getting better and more diverse. However, as we know that in the online sales and purchases system the products offered are only an explanation of the specifications of the goods and pictures that cannot be guaranteed. Thus, sales and purchases online applies sales and purchases system on 
Rif'atul Muzayanah et al: The Frame of Sharia Economic...

the internet. There is no direct contact between the seller and the buyer (Ministry of National Education, 2008). The subject of online sales and purchases is similar with conventional sales and purchases, namely business actors, as sellers who sell their goods and buyers as consumers who pay the price for goods. Most of the times, sales and purchases only based on trust, meaning that the actors of online selling are purchasing are sometimes obscure so they are fraud susceptible. (Nisrina Disa, 2015).

\section{Online sales and Purchases Components}

Based on the protocol standard of SET (Secure Electronic Transaction), components involved in the online sales and purchases are as follow: (Ridwan, 2015)

Virtual or Physical Smart Cards are media used by buyers or transaction actors to submit their credit cards to the cashier at the counter. The handover of this credit card is no longer done physically, but through a device called a smart card. With this smart card, the buyer will send the information from the credit card needed by the sellers to be carried out by the authorities for the information it gets.

Virtual Point of Sale; with this Virtual Point of Sale, buyers will really feel as if they are in a real shop or market place. The buyers can make the selection of the items needed. The buyers can also see how many items are available, find out how many items are sold, how many transactions have completed, and when the purchased goods will arrive without feeling anxious about the wrong bill or wrong debit on their cards.

Virtual Acquirer or Payment Gateway, the actual transaction of the seller to carry out the buyer's credit card authority to the bank that collaborates with the visa or master card (Ridwan, 2015) to confirm the validity of the credit card and to identify the credibility of the card holder. If there is no problem found from the credit card, the seller will send the buyer's transaction bill to the bank. This software can be placed in certain banks in collaboration with several merchants to build an online sales and purchases system or can also be placed at an ISP.

Visa Credit Card; Visa is a payment tool which $100 \%$ support online transactions on the internet. Visa collaborates with various banks around the world and various online sales and purchases software developers. Visa also provides a 
Islamiconomic: Jurnal Ekonomi Islam

Vol.12 No.1 January - June 2021

reliable and confidential data base that buyers can access at any time. (Ridwan, 2015).

\section{Online Sales and Purchases Platform}

There are several platforms used in online trading such as follow: (Ridwan, 2015).

1. Marketplace. Business actors display their sale products by uploading pictures along with the product descriptions in the marketplace.

2. Website. Online business actors can make internet site intended for their online business. These sites use their online stores' name as their domain addresses.

3. Forum. Oftentimes, these forums are provided by community-based websites. From these forums, people can find what they are looking for and what they should sell based on the society's demand.

4. Social Media.One of the most effective platforms to do an online business is social media that can reach society personally such as Facebook, Twitter, WhatsApp, etc.

\section{Payment Method}

Online trade consumers are demanded to have more awareness upon the process, risk, and safety of an online transaction. In Indonesia, there are several payment systems commonly used in online trade such as: (Ridwan, 2015).

1. Cash. Cash payment instruments can be made using money, either in forms of coins or banknotes. Although cash payment transactions have decreased, many consumers still feel comfortable using cash payments rather than noncash payments since the non-cash payments is seen more complicated for some people as it requires knowledge about the technology.

2. Interbank Transfer. This payment system is more popular than other payment systems since this transaction is effortlessly easy for consumers to use as the fund confirmation process can be quickly checked by the funds' recipients or the sellers.

3. COD (Cash on Delivery). In the COD payment system, it can actually be said that it is not an online sales and purchases process, for the seller and the buyer 
Rif'atul Muzayanah et al: The Frame of Sharia Economic...

meet in person, and a bargaining process might also occur. Even though the order is placed online, the payment process is direct (Maxmanroe, 2014).

4. Pulse Deduction. The method of pulse deduction is usually applied by online shops that sell digital products such as applications, music, ringtones, and games. This transaction is still dominated by transactions using mobile devices or smartphones. (Maxmanroe, 2014).

5. Credit Card. Credit card is one of the most popular means of payment for its convenience offered by banks. Cardholders are only required to enter credit card data, then the payment process is automatically carried out. (Maxmanroe, 2014).

6. Account Based Card. This payment instrument uses a card. The card's funds come from the customer's account. The types of cards that fall into this category are ATM cards, Debit Cards or a combination of ATM and Debit. (Eljah, 2016).

7. PayLater. This payment system is a financial facility that allows installment as payment methods without credit card. This payment method applies to all available product. (Novi, 2019).

\section{Shopee PayLater}

Shopee PayLater is an official product from Shopee. It offers payment with installment method which can be done with a credit card or without credit card. However, not all Shopee users can register for Shopee Paylater. Those who can register for Shopee Paylater are Shopee users who have used Shopee for at least 3 months, have verified accounts, and have frequent transaction histories at Shopee. In the Shopee PayLater, customers are allowed to take products and pay it later through installment method. For those Shopee users who cannot find Shopee PayLater logo appearing in their applications, means it has not met the requirements of Shopee PayLater. Hence, customers or users are suggested to first register to Shopee PayLater according to the provisions. (Anzilni, 2016). If accepted, the first loan limit given is IDR 750 thousand, which can be paid D-30 without interest. If the installments last for 2-3 months, interest will be added with the rate of $2.95 \%$ approximately. Billing details will appear every 25th and payment should no later 
Islamiconomic: Jurnal Ekonomi Islam Vol.12 No.1 January - June 2021

than the 5 th of the following month. Late payment will be be charged a $5 \%$ of the total bill fine per month. (Anzilni, 2016).

Shopee PayLater payments can be done via bank transfers such as BRI, Mandiri, BCA, BNI and other banks, used either ATM, Internet banking, or sms banking. If customers do not have bank account, they can choose the appointed convenient stores such as Indomaret and Alfamart as an option. To see the installments bill, customers can simply open the Shopee application> Me $>$ Shopee PayLater and the bill will appear at 25th every month. Currently, the Shopee PayLater can only be used for online shopping at Shopee and cannot be cashed out. The existence of this PayLater feature has further strengthens the competition among online market places players in meeting the users' needs to make everything easier and instant (Roudhoh, 2014).

\section{Islamic law}

Trading is a part of the Prophet's life journeys. His life in a merchant family making him involved in trading from a young age. He traded in an honest and ethical manner based on Islamic economics principal. In this trading activity there must be transactions between sellers and buyers, several strategies and types of transactions are also diverse, one of which is the installment system or commonly called credit (Rachel, 2017).

PayLater is a payment method using bailout funds from the related application company, then the user pays the bill to the application company. This feature is also useful for users who want to buy goods or travel without cash. In the science of Fiqh, the credit in sales and purchases contract is better known as taqsith which literally means to divide or make something into several parts. If the repayment is due and the buyer is not able to pay, then there must not any interest or additional money to be paid for the late payment. (Azhar Basyir, 2000).

From the explanation above, it is clear that the installment or credit payment system is allowed as long as it is still in accordance with Islamic principles. As good Muslims we must emulate what the Prophet did in his transactions in order to get blessings and be blessed by Allah SWT. (Adawiyah, 2015). It has been explained above that E-commerce and Bai 'As-salam are the results of trading practices reflections that adhered to by different times and socio-cultural conditions. Bai 'as- 
Rif'atul Muzayanah et al: The Frame of Sharia Economic...

salâm is the thought product of Islamic legal experts, while e-commerce is a Western product that is formed along with the development of information and communication technology. In order to formulate an appropriate description, it is necessary to first describe the specific identity that characterizes the following two transactions: (Taqiyuddin, 1995).

Pillars and terms of sales and purchases. According to Imam Nawawi in Syarah al-Muhadzab, the pillars of sales and purchases include three things, namely: there must be akid (the people who perform the contract), ma'qud 'alaihi (goods being contracted) and shighat, which consists of ijab (offer) qabul (acceptance)

$B a i^{\prime}$ As-salam transactions. From the various definitions mentioned, it seems that there are several points in agreement about this Bai 'As-salam transaction. First, it is stated that as-salam is a transaction or sales and purchases transaction. Second, there must be certain criteria for the transaction object/ al-muslam fih. Third, the object of the transaction/ almuslam fih must be under the sellers' responsibility/ ownership. (Taqiyuddin, 1995). As-salam transactions may be in accordance with the Qur'an and as-Sunnah and based on the underlying basis that in as-salam transactions that some elements are supporting the efforts to realize the benefit of the economy for all (mashlahah al-iqtishâdiyyah). As-salam transactions are rukhsah (a dispensation) for humans. The as-salam transaction makes humans' life easier. As the concept of the current global economy, where e-commerce is one of its manifestations, thus the implementation should be based on the rules that apply to each country where the transaction occurs. (Asnawi, 2004).

Bai 'as-Salam is based on al-Qur'an and al-Hadith and the results of the ijtihad of salaf scholars. And as previously explained, at least the realization of bai 'as-salam is due to the following reasons. There are elements in As-salaam transaction that are in line with the efforts of realizing the benefit of the economy for all (mashlahah aliqtishâdiyyah). As-salam transactions are rukhsah (a dispensation or something that relieves) for humans. As-salam transactions provide convenience to humans/people/society. (Asnawi, 2004). As with the current concept of the global economy, where e-commerce is one of its manifestations, its implementation is based on the rules that apply to each country where the transaction occurs. 
In contrast with e-commerce, bai 'assalam is a transaction model which application is based on fiqh mu'amalah for trade. For bidding/offers, bai' as-salam requires a sighat ijab qabul between the seller and the buyer with a contract to suspend the delivery of al-muslam fih or the object of the transaction. Statements of $i j a b$ and qabul can be done oraly, in written form, in correspondence form, or in the form of actions that have become customary in ijab and qabul, as explained by scholars such as al-Ghazali, an-Nawawi, and Imam al-Kasani (Ash-syari'i, tt).

As for e-commerce, offers are made by sellers or business actors through websites on the internet. The seller or business actor provides a storefront containing a catalog of products and services provided by the seller. In as-Salam the criteria for the product being offered (al-muslam fih) become the most critical things. Therefore, the product must be explicit and evident at the time of bidding. Something by which criteria cannot be identified should not be made as al-muslam fih because according to al-Bahuti it can lead to disputes between the transacting parties (Asy-syari'i, t.t.).

In the principle of sales and purchases in Islam, the object of the contract should be very clear and firm and should not contain prohibited elements by Allah's order. If that happens, the transaction is considered as a void transaction automatically. Meanwhile, in e-commerce, the object of the transaction is very diverse. This trading objects' diversity is depend on the country in which the transaction is carried out.

The current method of payment in sales and purchases is sophisticated as ecommerce recognizes not only direct but also indirect payments as long as it is under the financial system of the country where e-commerce take place (Yulaika, 2018). Upon technological advances, now payments can be made via credit cards by filling the credit card number on the form provided by the seller in the offer. As a consequence of electronic trading, it is hard to make payment directly for the location difference between the seller and the buyer although it is also possible to do so (Aqidatul, 2020).

In the e-commerce, there also known a term of goods delivery. This happens because the seller and the buyer do not live close together as they might be very far apart from their cities, regions and even countries. This delivery is made after payment has been made for the goods offered by the seller, in this case the buyer is entitled to receive the offered goods. (Yulaika, 2018). 
Rif'atul Muzayanah et al: The Frame of Sharia Economic...

As for the place for the goods' handover, according to the previous Islamic scholars, there has no place been specified as the Prophet did not emphasize this matter. As long as the place is agreed upon by both parties, representative, and can be reached by both of them, it can become a place for the goods' hand over (Faulidi, 2004).

\section{METHODOLOGY}

This research is field research type (Nisa, 2019). In 2019 researchers gather the data from applications regarding public knowledge of Shoppe PayLater payments. The type of research used is a type of qualitative research. Qualitative research is descriptive research which tend to use inductive analysis approach. The theoretical basis is used as a research guide so that the research focus is in accordance with the facts. This research was conducted for 3 months starting from February to April 2020. The data sources in this study were the subjects from which the data could be obtained. In qualitative research, the data are in the form of words, actions and the rest are additional data such as documents and others (Lexy, 2007). The words, actions, and documents of the people being observed and interviewed become the main data sources. This research is based on the researchers' focus and objectives, namely consumer knowledge of the Shoppe PayLater payment system.

\section{RESULT AND ANALYSIS}

\section{Mechanism of PayLater payment system in Shopee e-commerce}

Payment for goods shopping at Shopee with the PayLater E-commerce system is a service provided by Shopee to make it easier for users to shop online in their application. The interesting thing about shopping at Shopee using the PayLater payment system is that customers can enjoy installments with $0 \%$ interest in 1 month. (Widiya, 2017). To be able to use Shopee PayLater, customers have to fulfill special requirements and are required to follow Shopee PayLater terms and conditions. Since Shopee PayLater is the latest service from Shopee and is currently still in beta, thus, not all users can enjoy the service. 


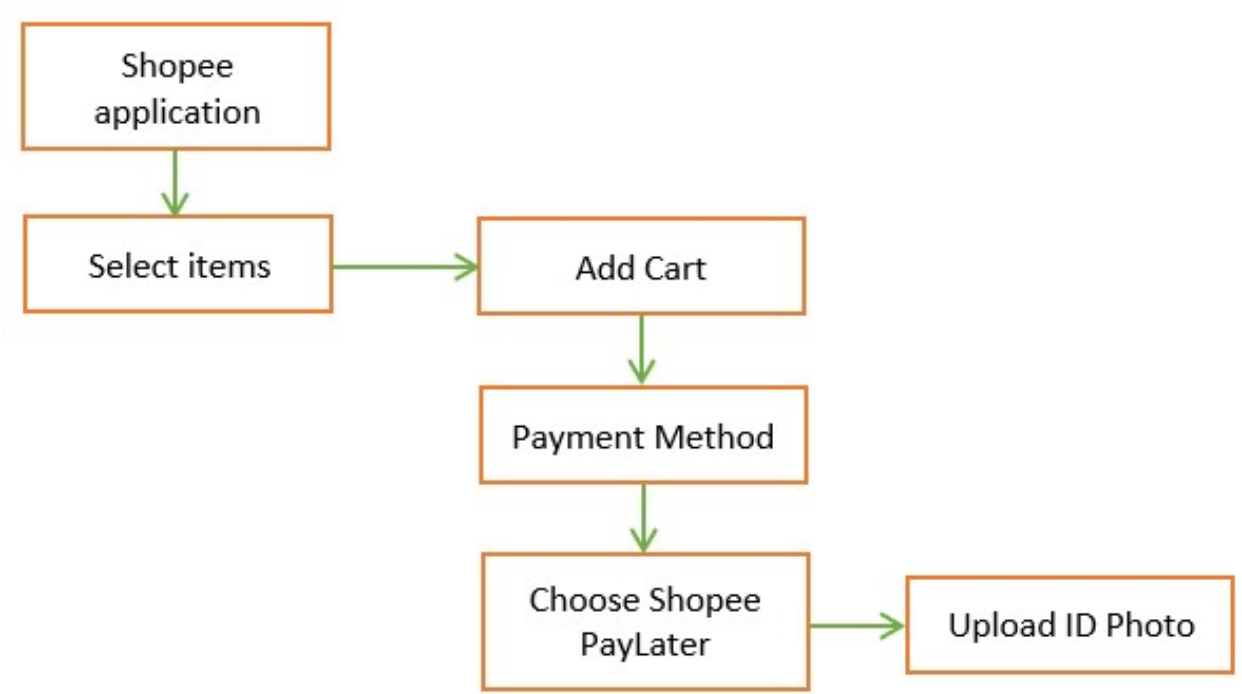

In dealing with and anticipating bad credit, Shopee PayLater using these following methods; 1 ) At the time of registering, Shopee asks for confirmation to be able to access all information, including all contact info on consumer smartphones, 2) When consumers or creditors are in arrears and do not pay off immediately. Shopee will contact all customers contacts as they have given Shopee permission to access, 3) Shopee has social and psychological impact in dealing with occurring bad credits. Shopee can access customers' contacts since the customers have agreed to give Shopee permission to access the entire list of contacts on their smartphones.

\section{Contracts Used in the PayLater Payment system in Shopee E-Commerce}

Based on its historical hierarchy, e-commerce is indeed a new transaction model that exists after the bai 'as-salam transaction. E-Commerce exists as a result of the rapid development of information technology in the 21st century. Normatively juridical, bai' as-salam originates from the practice of trade which was exemplified by the early generations of Islam and became the basis of one of the legalized tradin fiqh practices for centuries by Muslims. Bai 'as-salam and PayLater are both sales and purchases activities. Thus, just like a sale and purchase transaction, it requires at least 4 things that must be fulfilled; namely buyers, sellers, means of exchange (money), and goods to be traded or objects of transaction. However, the delivery of the object of transactions is postponed for PayLater and bai 'as-salam, even though there has been a sale and purchase agreement between the seller and the buyer. At the very 
Rif'atul Muzayanah et al: The Frame of Sharia Economic...

least, this is the basic similarity between PayLater and bai 'as-salam. Several specific differences are also found between the two concepts, especially in terms of the model of offer, payment, delivery and acceptance. This difference does not automatically imply that the PayLater method is invalid. However, there is a clear contradiction of PayLater with the principles and values of Islamic teachings in the field of mu'amalah. These contradictions include the elements of maisir (gambling), gharar (fraud), and usury. Therefore, the products or services offered are among those that prohibited by Islamic teachings.

\section{Overview of Islamic Law in PayLater payments in Shopee E-commerce}

Islam has emphasizes the permissible and prohibited elements of this sales and purchases transaction. Allah allows trading and forbids usury and all forms of sales and purchases transactions that contain elements of gharar (obscurity) in the contract. Al-Qur'an explicitly prohibits all business transactions that contain all forms of fraud against other parties which may be in the form of fraud or crime, or obtaining improper profits or risks leading to uncertainty in a business and its kind. (Yuana P, 2018).

Nowadays, social media is used as sales and purchases transactions platform. However, using Shopee PayLater payment method in these transactions is prohibited by religion. E-Comerce PayLater with the installment method clearly contains elements of unclear offers with $0 \%$ interest since the buyer cannot see the contract directly and cannot see the item being offered directly, and the transaction can simply be carried out using buyers' ID card. Thus, this is where the uncertainty in the online trading installment transaction takes place based on the Sharia law.

\section{E. CONCLUSION}

Based on the results of the research, the conclusions that can be drawn from the analysis are; firstly, the Shopee PayLater payment system mechanism is relatively easy and fast by having the Shopee application that can be freely downloaded on the Playstore and fulfilling easy requirements. On the PayLater menu there are options for the amount of nominal to choose. Secondly, the contract used in the Shopee PayLater is Bai 'As-Salam. Both Bai 'as-salam and e-commerce used in PayLater are 
Islamiconomic: Jurnal Ekonomi Islam Vol.12 No.1 January - June 2021

both buying and selling activities. Thus, here should be at least 4 requirements that must be fulfilled; namely the buyer, the seller, the medium of exchange (money), and the goods being traded or the object of the transaction. For the third, in the review of Islamic law, Shopee PayLater payments that use the 1 month payment method do not contain usury since there is no addition when its due. However, if the payment uses the 3/6/12 month installment system, Shopee will charged interest in the monthly payment. If the installment is due in 3 months the interest will be automatically added which causes usury. Lastly, e-commerce PayLater with this installment method clearly contains elements of ambiguity (gharar). Offerred with $0 \%$ interest, the buyers cannot see the installment contract directly and cannot see the items directly as they only sees photos of the items being offered. The buyers only prepare ID cards and are offered the $0 \%$ interest immediately. Thus, this is where the uncertainty lies in online transactions' installments system in Islamic sharia.

\section{F. REFERENCES}

Adawiyah, R. (2015). Hukum pembayaran dalam Islam (Online). https://dalamislam.com.

Amalia, R. (2019). Profil Shopee sebagai marketplace Indonesia tersukses. http//.Shopee.com.

Anzilni, A. (2016). E-comerce pada Shopee PayLater (Online). https://nekopencil.com/e-commerce/shopee-paylater/.

Aqidatul. (2020). Shopee Paylater menguntungkan. www. un clear.com.

Asnawi, H. F. (2004). Transaksi Bisnis E-commerce Perspektif Islam. Magistra Insani.

Assauri. (2018). Transaksi Keuangan Dulu dan Sekarang. https://www.payfazz.com.

Asy-syari'i, I. (t.t.). Prinsip-Prinsip Mu'âmalah. http://an-nuur.org.

Az Zuhaili, W. (2011). Fiqh Islam wa Adillatuhu. Juz 5. Gema Insani Press.

Azhar Basyir, A. (2000). Asas-asas Hukum Muamalat (hukum, Perdata Islam). UII Press.

Aziz, D. (2004). Ensiklopedi Hukum Islam, Jilid 3. PT Ichtiar Baru.

Dahlan Aziz, A. (2014). Ensiklopedi Hukum Islam Jilid 3 (2014 ed.).

Departemen Pendidikan Nasional. (2008). Kamus Besar Bahasa Indonesia Pusat Bahasa. Edisi IV (4 ed.). PT Gramedia Pustaka. 
Rif'atul Muzayanah et al: The Frame of Sharia Economic...

Eljah, I. (2016). Macam-macam Sistem Pembayaran pada Bisnis E- commerce (Online). https://www.daya.id/u.

Fasa, M. I., Febrianty, A., Khoerulloh, K., Arisa, A., Utami, W., Santoso, I. R., ... \& Haerany, A. (2020). Eksistensi BISNIS ISLAMI di era revolusi industri 4.0. Penerbit Widina.

Faulidi, H. (2004). Transaksi Bisnis Ecommerce. Magistra Insani.

Hendi, S. (2002). Fiqih Muamalat. PT Raja Grafindo Persada.

Jadmikio, E. (2020). Shoppe Paylater. https://shopee.co.id/.

Joko, J. (2015). Belanja Oline (Online). www.cermati.com.

Lexy, J. M. (2007). Metode Penelitian Kualitatif. PT Remaja Rosda Karya.

Malik. (2020). Apa yang dimaksud Pay Later (Online). www.prosesbayar.com.

Maxmanroe, M. (2014). 3 Jenis Transaksi Jual Beli Online Terpopuler di Indonesia. //www.maxmanroe.com/.

Nisa. (2019). Pengertian Penelitian Lapangan (Online). https://id.wikipedia.org.

Nisrina Disa, N. (2015). Tinjauan Hukum Islam Terhadap Jual Beli Online Dan Relevansinya Terhadap Undang-Undang Perlindungan Konsumen. 48.

Noegroho, A. (2010). Tegnologi Komunikasi. Graha Ilmu.

Novi, N. (2019). Paylater. https://shopee.co.id/.

Nugroho, B. (2019). Pengertian Internet (Online). http://budinugroho24.wordpress.com.

Rachel S., R. (2017). Apa Hukum paylater (Online). https://republika.co.id.

Ramdhan, A. (2017). Pengertian Sistem Pembayaran. http://repository.unika.ac.id.

Ridwan. (2015). Marketing Lima Tempat Jual Online. http//Marketing.blogspot.com/.

Roudhoh, R. (2014). Aplikasi layanan Pay later Semakin di Minati (Online). https://www.cermati.com.

Taqiyuddin, A. B. (1995). Hukum Jual Beli Islam. CV Bina Iman.

Widiya, R. (2017). Pembayaran dalam Shopee Paylater (Online). www.prosesbayar.com.

Yuana P. (2018). Transaksi pembayaran dalam Bisnis Islam ( Online). www.kangsantri.id.

Yulaika, Y. (2018). E-Comerce (Online). http://repository.unika.ac.id/. 